\title{
STRUKTUR FRASA PREPOSISI BAHASA MANDARIN
}

\author{
Titi Rahardjanti \\ Sastra China, Faculty of Humanities Binus University \\ titi.leimeihui@gmail.com
}

\begin{abstract}
Abstrak
Penelitian ini mengkaji frasa preposisi lokatif dan temporal bahasa Mandarin berdasarkan teori X-bar. Tujuan penelitian untuk mendeskripsikan struktur frasa preposisi lokatif dan frasa preposisi temporal, adapun metode yang digunakan adalah deskriptif kualitatif. Metode pengumpulan data menggunakan metode simak, metode analisis data menggunakan metode agih yang perilakunya disesuaikan dengan teori X-bar. Temuan penelitian ini adalah (1) preposisi 在 (zài - di), 于 (yú - pada), 从 (cóng - dari), 自 (zì - dari) dan 到 (dào - ke) dapat berperan sebagai preposisi lokatif, temporal maupun gabungan keduanya (2) preposisi 在 (zài - di), 于 (yú - pada), 从 (cóng - dari), 自 (zì - dari) dan 到 (dào - ke) jika bergabung menjadi frasa preposisi dalam kalimat memiliki fungsi sintaksis sebagai adjung atau komplemen.
\end{abstract}

Kata Kunci : Frasa preposisi bahasa Mandarin, teori X-bar

\begin{abstract}
This research focuses on Mandarin locative and temporal preposition phrases based on the Xbar theory. The research aims to describe the structure of Mandarin locative and temporal preposition phrases. The method uses descriptive qualitative. The data collection uses 'simak' method, and data analyzing uses 'agih' method, which the behavior has been adjusted based on X-bar theory. The results of the analysis shows that the preposition of 在 (zài - in), 于 (yú - in), 从 (cóng - from), 自 (zì - from) and 到 (dào - to) can act as a locative and temporal preposition or a combination of both (2) the preposition 在 (zài - in), 于 (yú - in), 从 (cóng from), 自 (zì - from) and 到 (dào - to), if join in sentence as a prepositional phrase have the syntactic function as adjunct or complement.
\end{abstract}

Key words : Mandarin prepositions phrase, X-bar theory

\section{A. PENDAHULUAN}

Bahasa Mandarin (BM) berdasarkan tipologinya masuk dalam bahasa bertipe isolatif (bukan monosilabis). Kaitan dengan gramatikal BM didasarkan pada urutan kata, dan bentuk katanya tidak mengalami perubahan secara morfologis, perubahan yang ada karena perbedaan nada (Li \& Thompson, 1989:26). Contoh kalimat BM sebagai berikut.

\begin{tabular}{|c|c|c|c|}
\hline 我 Wǒ & 在 zài 家 jiā & 吃 chī & 饭 fàn. \\
\hline Noun $(\mathrm{N})$ & Frasa Preposisi (FP) & Verba (V) & Noun \\
\hline Subyek (S) & FP & Predikat (P) & Obyek (O) \\
\hline
\end{tabular}




\section{Bahasa Indonesia (BI) : Saya makan di rumah.}

Pada kalimat (1) di atas urutannya adalah S-FP-V-O, unsur subyek adalah 我 (Wǒ saya), frasa preposisi (FP) adalah 在家 (zài jiā - di rumah), unsur predikat adalah 吃 (chī makan), dan objeknya adalah 饭 (fàn - makanan). Kalimat dalam BM, FP itu muncul karena ditentukan oleh urutan waktu (The Principle of Temporal Sequence, Tai (1985), maka pada contoh kalimat (1) di atas FP BM terletak di depan predikat verba. Selain itu, hal ini juga berkaitan dengan filosofi budaya dan tradisi hidup orang Tionghoa, untuk menyatakan kegiatan yang dilakukan dalam kebiasaan hidup sehari-hari diekspresikan dengan urutan waktu yang didahulukan. Filosofis dalam kalimat (1) adalah 我 (wǒ - saya) harus tiba di rumah lebih dahulu, baru 吃饭(chīfàn - makan), bukan makan dahulu baru tiba di rumah. Ini merupakah salah satu kelebihan dari BM. Selain itu terdapat beberapa FP yang mempunyai fungsi dan makna ganda. Contoh:

(1) a. 妈妈 Māmā

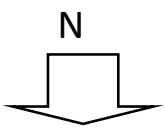

$\mathrm{S}$

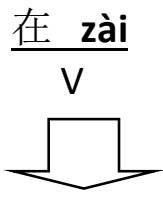

$P$

di

家 jiā.

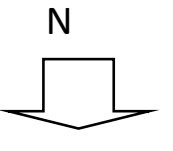

O

rumah

BI : Ibu berada di rumah.

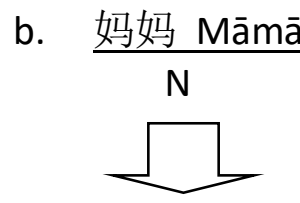

$\mathrm{S}$

Ibu

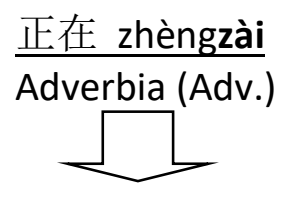

Adverbia

sedang

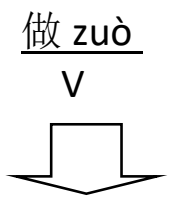

$P$

$B I$ : Ibu sedang memasak.

c. 妈妈 Māmā 在㷴房 zài chúfáng 做饭 zuò fàn.

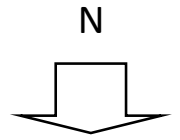

$\mathrm{S}$

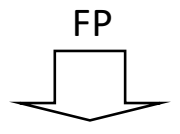

FP

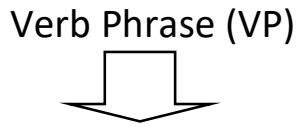

P

BI : Ibu memasak di dapur. 
Pada kalimat (2a) 在(zài-di) berfungsi sebagai verba yang menunjukkan keberadaan dari dari subjek yaitu 妈妈 (Māmā - Ibu), sedangkan pada kalimat (2b) 在(zài - di) bergabung dengan 副词 (fuci - kata keterangan) 正 (zhèng) menjadi 正在(zhèng zài), berfungsi sebagai adverbia, yang bermakna sedang, menunjukkan suatu aktivitas 做 (zuo memasak) sedang berlangsung. Selanjutnya 在 (zài) pada kalimat (2c) berfungsi sebagai preposisi lokatif karena kata yang mengikuti 在(zài) adalah nomina yang mengacu pada lokasi, preposisi 在(zài) dengan nomina lokasi 的房 (chúfáng - dapur) membentuk FP lokatif 在 㕌房(zài chúfáng) yang bermakna 'di dapur' . Lu (2006:645) mengatakan 在 (zài) memiliki fungsi sebagai verba, adverbia dan preposisi, seperti pada contoh kalimat (2) di atas.

Selain preposisi 在(zài) yang memiliki fungsi dan makna ganda seperti di atas, terdapat preposisi lain yaitu 从(cóng - dari), 到 (dào - ke), dan 自( zì - dari). Preposisi dalam BM menempati posisi yang penting karena frekuensi pemakaian yang tinggi di dalam BM sehari-hari. Persoalan yang paling mendasar bagi pembelajar BM adalah fungsi dan makna ganda yang dimiliki oleh preposisi 在(zài), yaitu kesulitan membedakan fungsi dan makna ganda yang ditimbulkan oleh preposisi ini, sehingga penelitian ini fokus kajiannya pada lima preposisi 于 (yú - pada), 从 (cóng - dari), 自 (zì - dari) dan 到 (dào - ke) adalah preposisi yang memiliki fungsi dan makna yang sama dengan 在 (zài), tetapi lebih banyak digunakan dalam bahasa tulis.

Tujuan yang ingin dicapai dalam penelitian ini adalah mengindentifikasi apakah kelima FP berfungsi sebagai penanda lokatif dan temporal, dan fungsi sintaksisnya sebagai adjung atau komplemen dalam kalimat.

Sumber data penelitian ini adalah kalimat yang ada dalam surat kabar Guoji, dengan alasan surat kabar Guoji merupakan surat kabar berbahasa Mandarin terbitan Indonesia yang memiliki oplah terbesar di Indonesia, sehingga mudah diperoleh dan diakses. Kalimat yang diambil untuk penelitian ini adalah berasal dari edisi bulan Nopember 2014 sampai dengan edisi Januari 2015.

Beberapa penelitian yang relevan dengan penelitian ini diantaranya adalah penelitian oleh Leng (2008) yang berjudul "Research on the Syntactic Position of the Prepositional Phrase “在(Zài) $+X$ ” and the Occurrence of the Preposition “在(Zài)”, Liang (2008) dalam penelitiannya yang berjudul "Comparison and Researches on the Location and 
Time Preposition in Present Chinese”, Zelia (2012) dalam tesisnya yang berjudul "Perbandingan FP BI dan BM (Suatu Analisis Kontrastif)", Anas (2012) dalam tesisnya yang berjudul "The Analysis of Common Error Made by Indonesian Students Learning Chinese Prepositional Phrase “在(Zài) + NP."

Penelitian pertama oleh Leng (2008) membahas tentang penggunaan dan pelesapan preposisi BM zài ' $d i$ ' di dalam kalimat. Hasil analisis menunjukkan bahwa jika zài berada di belakang predikat tidak dapat dilesapkan. Penelitian kedua oleh Liang (2008) menelaah preposisi lokatif dan preposisi temporal dalam BM. Penelitian ketiga oleh Annas (2012) membandingkan preposisi 在 (zài) dengan preposisi BI pada/di, lalu menelaah FP BM "在 (Zài) + Frasa Nomina (FN)" dan FP dalam BI "di/pada + FN" melalui analisis kesalahan. Penelitian keempat oleh Zelia (2012) membandingkan FP BI dan BM dengan menelaah susunan unsur kalimat yang mengandung preposisi atau FP.).

Penelitian ini bersifat melengkapi penelitian di atas, karena penelitian ini lebih difokuskan pada struktur frasa dan pembuktian atas kegunaan FP dan fungsi sintaksis FP BM. Teori yang digunakan untuk membuktikan fungsi sintaksis tersebut adalah teori X-Bar.

Teori X-Bar adalah bagian dari Government and Binding Theory (GB) yang dikemukakan oleh Radford (1997) dan Newson (2006). Teori GB menggambarkan struktur frasa dan struktur batin dari kalimat teori GB merupakan sebuah teori lanjutan dari teori tata bahasa Transformasi Gramatika Generatif (TTG) yang bertujuan untuk memberikan pemerian yang sistematik tentang kalimat bahasa dengan mengajukan satu analisis gramatikal sangat diperlukan untuk mendapatkan deskripsi gramatikal yang baik (Pujiono, 2014).

Dalam teori X-bar, semua frasa dijelaskan dengan satu inti leksikal. Inti merupakan pemarkah bagi ciri kategorinya. Setiap ini proyeksi yang ditandai (X') merupakan simpul akhir (terminal node) yang mendominasi kata dan dapat iteratif (berulang) (Hargemen, 1991: 84). Inti yang dimaksudkan adalah inti dari Frasa Verbal (FV) adalah verba, inti dari Frasa Nomina (FN) adalah nomina, inti dari Frasa Adjektival (FA) adalah adjektiva, dan inti dari Frasa Numeralia (FNum) adalah numeralia. Misalnya menulis merupakan inti verba pada frasa sedang menulis. Maka sedang menulis dikatakan FV. Selanjutnya teori X-bar direpresentasikan pada diagram pohon (disebut juga tataran sintaksis). Pada tataran ini sebuah kategori leksikal seperti verba, nomina, adjektiva, atau numeralia (dalam hal ini disimbolkan dengan $\mathrm{X}$ ) dibentuk oleh komplemen, keterangan dan spesifier. Komplemen berkombinasi dengan $\mathrm{X}$ membentuk proyeksi X-bar, keterangan berkombinasi dengan X-bar (X') 
membentuk X-bar lebih tinggi ( $\left.\mathrm{X}^{\prime}\right)$ dan spesifier berkombinasi dengan $\mathrm{X}$-bar lebih tinggi membentuk proyeksi maksimal frasa X. Jadi proyeksi X merupakan kategori bar.

Inti mempunyai properti berikut. Pertama, inti memarkahi ciri kategorinya, contohnya, inti dari FN adalah nomina, inti dari FV adalah verba dan inti dari FP adalah preposisi. Kedua, inti terletak satu level lebih rendah dalam hierarki X-bar daripada konstituen yang menjadi inti tersebut. Sehingga, dalam hierarki $\mathrm{X}$ - bar preposisi (P), sebagai inti dari FP terletak satu level lebih rendah dari frasanya. Kategori ini mempunyai bar kosong atau tanpa bar.

Haegemen (1992:95) dalam Introduction to Government on Binding Theory mengatakan bahwa semua frasa dalam teori X-bar didominasi oleh sebuah inti leksikal. Inti adalah simpul akhir (terminal node) yang mendominasi kata. Inti merupakan pemarkah bagi ciri kategorinya. FP misalnya didominasi oleh P (Preposisi) sebagai inti. Berdasarkan pendapat (Haegeman, 1992:95), secara umum kaidah struktur frasa menurut teori X-Bar adalah sebagai berikut.

$$
\begin{aligned}
& X^{\prime \prime} \rightarrow \text { Spec; X' } \\
& X^{\prime} \rightarrow X^{\prime}: Y P \\
& X^{\prime} \rightarrow \text { X; YP }
\end{aligned}
$$

Kaidah ini dapat berarti bahwa:

X” adalah maksimal suatu frasa yang terdiri dari Specifier (Penentu) yang berkombinasi dengan $\mathrm{X}^{\prime}$ (proyeksi teratas).

Hal ini dapat digambarkan sebagai berikut:

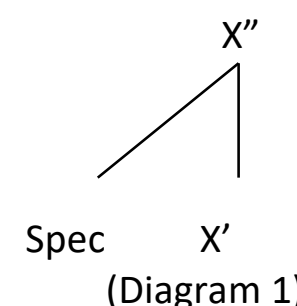

$\mathrm{X}^{\prime}$ adalah sebuah proyeksi teratas yang terdiri dari X-bar yang berkombinasi dengan Adjung (keterangan) yaitu YP.

Diagram pohonnya adalah sebagai berikut:

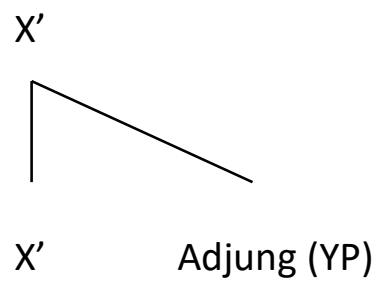

(Diagram 2) 
$X^{\prime}$ adalah sebuah proyeksi yang terdiri dari X (kategori leksikal frasa) yang berkombinasi dengan komplemen yaitu YP.

Diagram pohon dari pernyataan ini adalah:

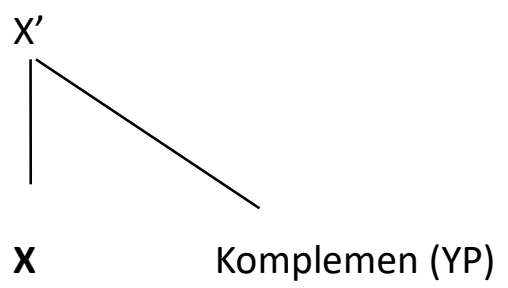

(Diagram 3)

Secara umum diagram pohon dari kaidah struktur frasa di atas adalah:
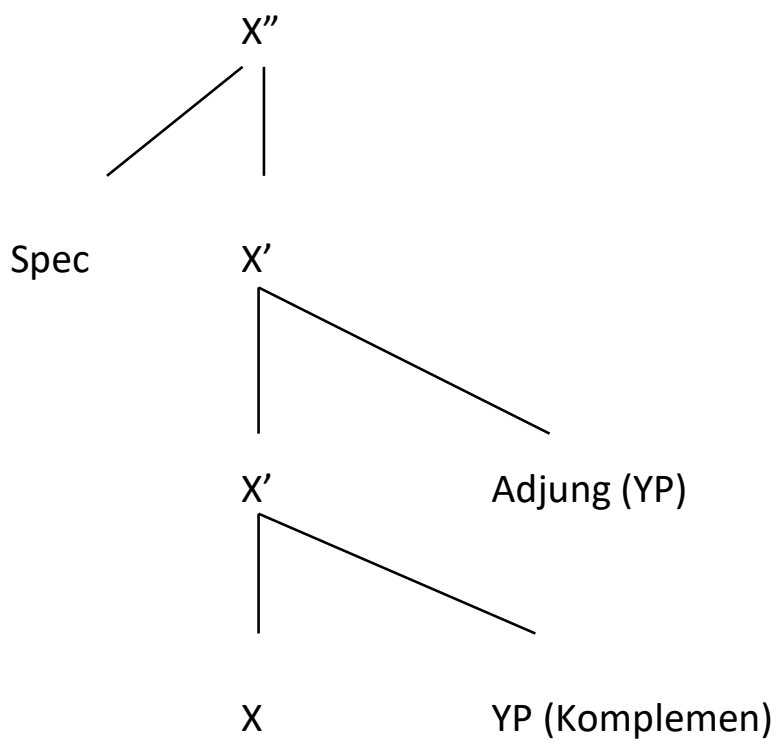

(Diagram pohon 4)

Dari diagram pohon struktur frasa di atas, terlihat ada tiga cabang, yaitu cabang $X$ sebagai inti frasa, kedua, cabang yang berada di sebelah kanan, dan ketiga adalah cabang yang berada di sebelah kiri. Cabang yang berada di sebelah kiri dari inti frasa disebut sebagai subjek atau penentu (specifier), cabang yang berada di sebelah kanan merupakan objek atau komplemen. Jika frasa mempunyai keterangan (adjung), maka keterangan itu di munculkan pada kategori $X$ yang lain. Keterangan (adjung) merupakan elemen yang tidak disubkategorikan dalam kerangka argumen bagi suatu frasa, tidak berlaku pada penentu (specifier), dan komplemen, yang merupakan keterangan tambahan pada struktur itu.

\section{B. METODE PENELITIAN}

Metode penelitian yang digunakan dalam penelitian ini adalah metode penelitian deskriptif kualitatif. Metode penelitian ini berusaha mendeskripsikan gejala (fenomena) 
seperti apa adanya, karena penelitian ini dimaksudkan untuk mendapatkan gambaran sifat keadaan atau fenomena-fenomena kebahasaan secara alami yang ada dalam BM.

Objek dalam penelitian ini adalah artikel surat kabar berbahasa Mandarin yang terbit di Indonesia. Dari sumber tertulis, yakni surat kabar tersebut, teknik penyediaan data dilakukan melalui beberapa tahap, yakni (1) mengidentifikasi kalimat-kalimat yang mengandung Frasa Preposisi Lokatif (FPrL) dan Frasa Preposisi Temporal (FPrT), (2) mencatat kalimat-kalimat tersebut dalam kartu data, (3) mengklasifikasikan kalimat yang mengandung FPrL dan FPrT berdasarkan kategorinya, (4) mendeskripsikan pola-pola serta kaidah penggunaannya, dan (5) melakukan analisis melalui interpretasi FPrL dan FPrT berdasarkan konteks kalimatnya.

Kalimat penelitian ini bersumber dari surat kabar berbahasa Mandarin Guoji periode tiga bulan, Nopember 2014-Januari 2015 dengan memakai metode simak. Kalimat dikelompokkan berdasarkan kesamaan tipe dan perilakunya dikaji dengan metode distribusional. Beberapa teknik analisis yang diterapkan teknik ganti, lesap, sisip, perluas, balik dan ubah wujud. Penerapan teknik ini bertujuan membuktikan keberadaan P' dalam struktur FP, dan untuk menjelaskan status dan perilaku fungsi gramatikal seperti komplemen, adjung, dan atributif.

Analisis data dilakukan setelah data diidentifikasi dan diklasifikasi. Klasifikasi data dilakukan sesuai dengan masalah penelitian, yakni melalui tindakan pengamatan, pembedahan, dan penguraian masalah. Analisis data menggunakan metode agih (Sudaryanto 1993:15). Dari alat penentu referen bahasa akan digunakan untuk mengetahui identitas Frasa Preposisi Lokatif (FPrL) dan Frasa Preposisi Temporal (FPrT) dalam kalimat bahasa Mandarin. Identitas masing-masing dapat diketahui dengan teknik menghubung-bandingkan satuan-satuan lingual yang terkandung dalam FPrL dan FPrT dengan referennya guna memperoleh kesamaan dan perbedaan di antara keduanya. Setelah itu data dianalisa lagi dengan menggunakan teori $\mathrm{X}$ - Bar untuk membuktikan kekuatan atas hasil analisis yang berhubungan dengan fungsi sintaksis FP. Prosedurnya sebagai berikut: (1) kalimat yang sudah diseleksi menurut pola-pola tertentu diuji perilakunya dalam kalimat; (2) kalimat itu kemudian dianalisis berdasarkan teori X-bar; (3) kalimat-kalimat yang sudah dianalisis dirumuskan generalisasinya.

Dalam penelitian ini hasil analisis data disajikan secara formal, yakni dengan menggunakan tanda atau lambang, seperti (FP) untuk Frasa Preposisi, (PREP) untuk preposisi, dan asterisk (*) untuk bentuk kebahasaan yang tidak berterima, Selanjutnya, 
metode informal digunakan untuk mendeskripsikan dan menjelaskan kaidah-kaidah FPrL dan FPrT serta konteks kalimatnya agar mudah dipahami oleh pembaca.

\section{PEMBAHASAN}

Dari analisis terhadap data penelitian, diperoleh temuan sebagai berikut: 1) Terdapat 24 FPrL (Frasa Preposisi Lokatif) dan 26 FPrT (Frasa Preposisi Temporal), dan 2) Terdapat 30 FP yang berfungsi sebagai adjung dan 20 FP sebagai komplemen.

\section{Frasa Preposisi Lokatif}

Preposisi dalam BM secara umum tidak dapat menjadi unsur kalimat sebelum bergabung dengan kata lain dan membentuk FP. Preposisi Lokatif (PrL) adalah preposisi yang menjadi penanda lokasi kejadian, secara konkret menunjukkan tempat keberadaan benda dan pergeseran dari suatu benda, termasuk titik awal, titik akhir, titik yang dilalui, dan arah. Secara struktur, preposisi lokatif diikuti nomina dengan makna lokasi

Dari hasil analisis, kalimat FP yang termasuk dalam FPrL ada 24 kalimat. Contoh pembahasannya adalah sebagai berikut.

\section{Campina 冰淇淋公司在 泗水伦古特工业区

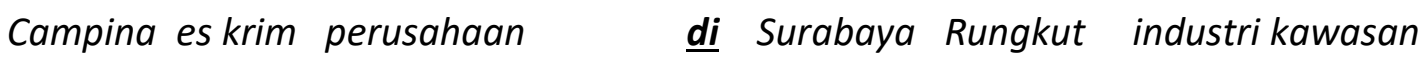

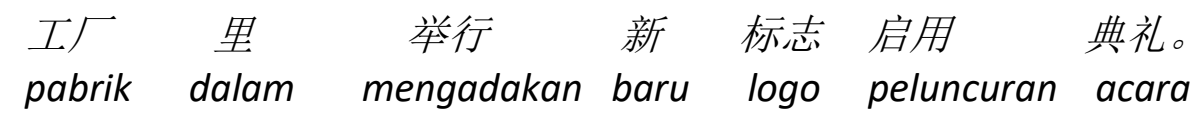

BI: Perusahaan es krim Campina mengadakan acara peluncuran logo baru di pabrik kawasan industri Rungkut Surabaya.

(Guoji, 1 Desember 2014)

Pada kalimat no. 17 di atas, preposisi 在 (zài-di), diikuti oleh nomina yang menunjukkan lokasi, yaitu 泗水伦古特工业区工厂里 (Sìshuǐ Lún gǔ tè gōngyè qū gōngchăng lǐ - pabrik kawasan industri Rungkut Surabaya). Gabungan preposisi dan nomina lokasi tersebut, membentuk Frasa Preposisi Lokatif (FPrL) zài sishuǐ Lún gǔ tè gōngyèqu gōngchăng lĭ, yang bermakna 'di pabrik kawasan industri Rungkut Surabaya', yang menunjukkan lokasi perusahaan es krim Campina mengadakan acara peluncuran logo baru.

Contoh lain adalah pada pembahasan kalimat no. 38 seperti di bawah ini:

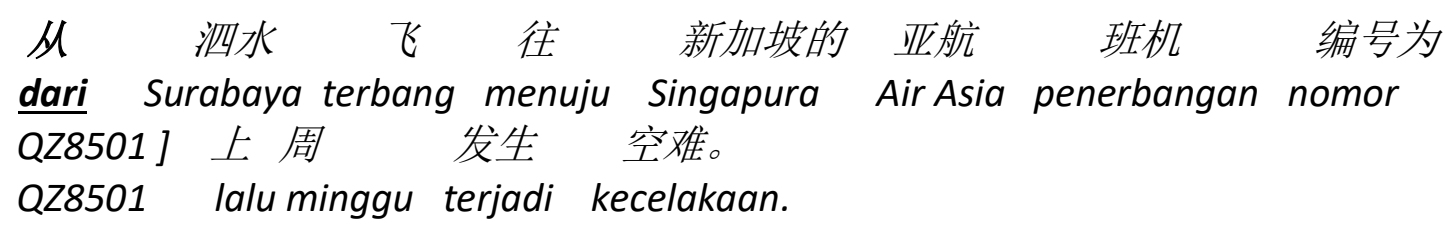


BI : Pesawat Air Asia nomor penerbangan QZ8501 dari Surabaya ke Singapura telah terjadi kecelakaan pada minggu lalu.

(Guoji, 6 Januari 2015)

Preposisi 从 (cóng - dari) pada kalimat no. 38 di atas, diikuti oleh nomina yang menunjukkan lokasi, yakni 泗水(Sìshǔ̌ - Surabaya). Gabungan preposisi dan nomina ini membentuk FP 从泗水 (cóng Sìshuǐ - dari Surabaya). Preposisi 从 (cóng) bermakna 'dari' karena menjadi penanda titik awal terjadinya kegiatan yaitu 飞往 新加坡的亚航班机 (fēi wăng Xīnjiāpō de Yàháng bānjī), 编号为

(biānhào wèi QZ8501) yang bermakna "penerbangan Air Asia nomor penerbangan QZ8501 dari Surabaya menuju Singapura'.

Dari contoh pembahasan kalimat no 17 dan 38 diatas, dapat disimpulkan bahwa Preposisi Lokatif dapat diidentifikasi dengan melihat nomina yang mengikuti preposisi tersebut.

\section{Frasa Preposisi Temporal}

Frasa Preposisi Temporal (FPrT) adalah FP yang menyatakan kewaktuan, biasanya terdiri atas preposisi dan pelengkap yang berupa nomina waktu. FP temporal BM antara lain 在 (zài - pada), 从 (cóng-dari), 到 (dào-hingga), 自 (zì - dari), 于(yú-pada).

Dari hasil analisis, kalimat yang termasuk dalam FPrT ada 26 kalimat. Contoh pembahasannya adalah kalimat no. 32 , seperti berikut ini:

莫巴拉克的终审判决本应在 9 月 27 日做出。 Hosni Mubarak pengadilan keputusan ini seharusnya pada September tgl 27 mengeluarkan.

BI: Keputusan pengadilan Hosni Mubarak seharusnya dikeluarkan pada tanggal 27 September ini.

(Guoji, 30 Desember 2014)

Preposisi 在 (zài - pada) pada kalimat no. 32 di atas, adalah Preposisi Temporal. Berdasarkan struktur kalimat di atas, preposisi 在 (zài) diikuti oleh nomina yang menunjukkan waktu yaitu 9 月(yuè) 27 日(rì) bermakna tanggal 27 September. Gabungan preposisi dan nomina tersebut membentuk Frasa Preposisi Temporal (FPrT) yakni 在 9 月 27 日(zài 9 yuè 27 rì) bermakna pada tanggal 27 September. Preposisi 在 (zài) pada FP 
tersebut bermakna pada, yang menunjukkan waktu, yaitu 9 月 yuè 27 日 rì . sebagai awal mula terjadinya suatu keadaan. Contoh lain dari pembahasan FP temporal ini adalah kalimat no 30, sebagai berikut.

从1992 年的洛杉矶种族骚乱到如今 多蔓延 $\underline{\text { dari }}$ tahun 1922 Los Angeles etnis kerusuhan hingga sekarang banyak menyebar 至百个城市。 hingga ratusan kota.

$\mathrm{BI}$ : Kerusuhan etnis di Los Angeles dari tahun 1992 hingga sekarang telah menyebar hingga ke ratusan kota.'

(Guoji, 18 Desember 2014)

Pada kalimat no 30 di atas, terdapat dua buah preposisi yaitu preposisi 从 (cóng - dari) dan preposisi 到 (dào - hingga) yang membentuk Preposisi Temporal gabungan yaitu 从 ..... 到 (cóng....dào - dari...hingga). Preposisi 从 (cóng) diikuti oleh nomina waktu, yaitu 1992 年 (nián-tahun) 'tahun 1992' membentuk Frasa Preposisi Temporal, yakni 从 1992 年 (cóng nián) yang bermakna dari tahun 1992. Preposisi 从 (cóng-dari) adalah preposisi penanda temporal titik awal terjadinya sebuah peristiwa, yaitu从 1992 年的洛杉矶种 族 骚 乱 (cóng 1992 nián de luòshānjī zhǒngzú sāoluàn - dari kerusuhan etnis di Los Angeles tahun 1992', sedangkan 到 (dào-hingga) diikuti oleh 如 今 (rújīn - sekarang) adalah sebagai penanda temporal titik akhir.

Dari contoh pembahasan diatas, dapat disimpulkan bahwa, Frasa Preposisi Temporal diidentifikasi dengan melihat nomina yang menunjukkan "kewaktuan" yang mengikutinya. Selanjutnya, dalam satu kalimat bisa dimungkinkan ditemukan gabungan dua atau bahkan tiga buah Preposisi Temporal.

\section{Struktur Frasa Preposisi Bahasa Mandarin}

\section{(1) Frasa Preposisi Sebagai Adjung}

Berdasarkan analisis struktur FP BM melalui rekonstruksi kalimat dan dengan menggunakan teori X-Bar, pada 50 data penelitian, diperoleh hasil bahwa 30 FP berfungsi sebagai adjung dan 20 FP sebagai komplemen. Contoh pembahasan adalah seperti di bawah ini: 
AKRA 公司计划 于 明年东爪省锦石

AKRA perusahaan berencana pada tahun depan di Timur Jawa propinsi Gresik 建设两台电机。

membangun dua buah pembangkit listrik

$\mathrm{BI}$ : Perusahaan AKRA berencana pada tahun depan membangun dua buah pembangkit listrik di Gresik Propinsi Jawa Timur.

Pada kalimat di atas, Frasa Preposisi Temporal (FPrT) 于明年(yú míngnián - pada tahun depan) dan Frasa Preposisi Lokatif (FPrL) 在东爪省锦石(zài Dōng Zhua shěng Jĩn shí - di Gresik Propinsi Jawa Timur) berfungsi sebagai adjung. Hal itu dikarenakan dalam BM FP yang letaknya di depan predikat verba, maka berfungsi sebagai adjung. Perhatikan rekonstruksi kalimat berikut :

a. AKRA 公司计划 $\{[$ F P r T [ PrT 于 明年 $]\}\{[$ F P r L P Prep 在 AKRA perusahaan berencana pada tahun depan di 东爪省锦石建设两台电机。

Timur Jawa propinsi Gresik membangun dua buah pembangkit listrik $\mathrm{BI}$ : Perusahaan AKRA berencana pada tahun depan membangun dua buah pembangkit listrik di Gresik Propinsi Jawa Timur.

b. AKRA公司计划建设电机。 AKRA Perusahaan berencana membangun pembangkit listrik $\mathrm{BI}$ : Perusahaan AKRA berencana membangun pembangkit listrik

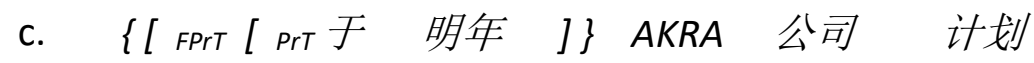

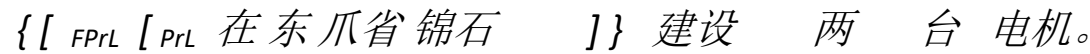

BI : Pada tahun depan perusahaan AKRA di Gresik Propinsi Jawa Timur berencana membangun dua buah pembangkit listrik.

d. * $\{[$ FPrL [ PrL 在东 爪省锦石 $]\} A K R A$ 公司 Di Timur Jawa Propinsi Gresik perusahaan AKRA

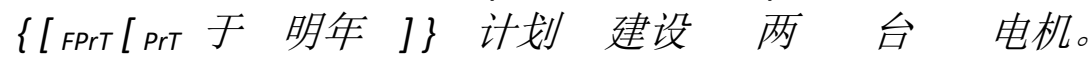
Pada tahun depan berencana membangun 2 unit pembangkit listrik. BI : di Gresik Propinsi Jawa Timur, perusahaan AKRA pada tahun depan berencana membangun 2 unit pembangkit listrik.

Pada rekonstruksi kalimat (29a) posisi Frasa Preposisi Temporal (FPrT) 于明年 (Yú míngnián - pada tahun depan) dan Frasa Preposisi Lokatif 在 东爪省锦石 (zài Dōng Zhua shěng Jǐn shí - di Gresik Propinsi Jawa Timur) di depan predikat verba, dalam BM kalimat ini dapat berterima. Kalimat (29b) FPrT 于明年 (Yú míngnián - pada tahun depan) dan FPrL 在 东爪省锦石 (zài Dōng Zhua shěng Junn shí - di Gresik Propinsi Jawa Timur) 
dilesapkan, menjadi kalimat inti yakni AKRA 公司 建设 电机 (AKRA gōngsī jiànshè diànjī - perusahaan AKRA membangun pembangkit listrik), kalimat ini masih berterima. Hal ini menunjukkan bahwa FP berfungsi sebagai adjung, yang sifatnya opsional, maka ketika dilesapkan kalimat intinya masih berterima. Kalimat (29c), FPrL 在 东爪省锦石 (zài Dōng Zhua shěng Jǐnshí - di Gresik Propinsi Jawa Timur) posisinya dipindah menduduki posisi FPrT 于 明年 (yú míngnián - pada tahun depan), maknanya berterima tetapi tidak gramatikal, karena dalam BM jika terdapat dua FP dalam satu kalimat, maka urutannya, FPrT posisinya di depan FPrL (Borong, 1997:85). Kalimat (29d) FPrL 在 东爪省锦石 (zài dōng zhua shěng Jǐnshí - di Gresik Propinsi Jawa Timur) dipindah posisinya di depan subyek AKRA 公司 (AKRA gōngsī - perusahaan AKRA), makna kalimat ini berterima, tetapi tidak gramatikal, karena dalam BM urutan FP yang berfungsi sebagai adjung posisinya selalu berada di depan predikat.

Dari pembahasan diatas, dapat disimpulkan FPrT 于明年 (yú míngnián - pada tahun depan) dan FPrL 在 东爪省锦石 (zài Dōng Zhua shěng Jǐnshí - di Gresik Propinsi Jawa Timur), adalah adjung karena kehadiran konstituen ini pada kontruksi sintaksis bersifat opsional. Sifat opsional inilah yang membedakan FP sebagai adjung dengan FP sebagai komplemen. IP

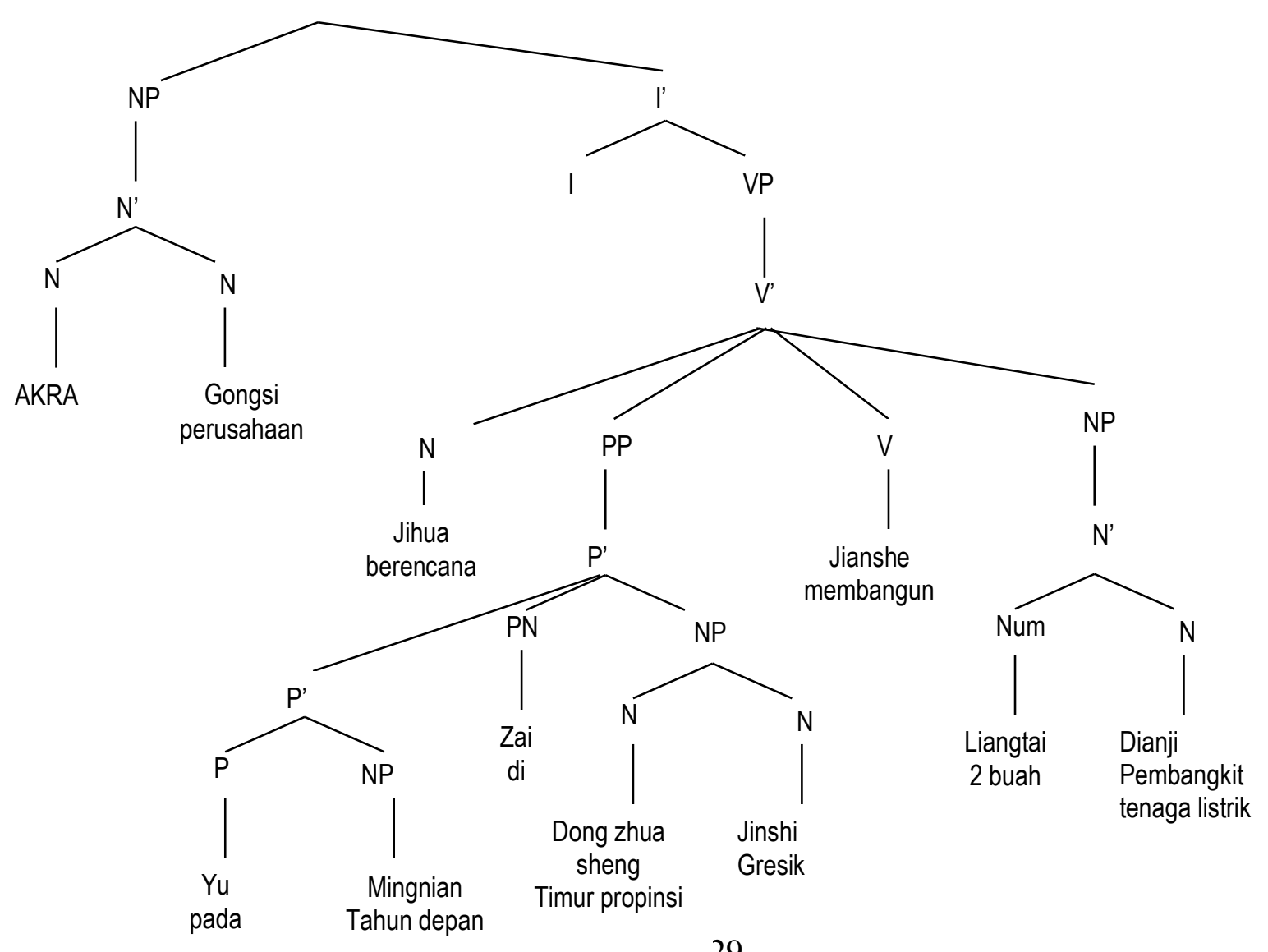


Pada diagram di atas, FPrT 于明年(yú míngnián - pada tahun depan) dan FPrL 在东 爪省锦石 (zài Dōng Zhua shěng Jǐnshí - di Gresik Propinsi Jawa Timur) posisinya di sebelah kiri Verba berada di bawah V-bar, sementara FP yang ini letaknya berdekatan dengan V-bar berada di bawah V-bar, maka FP tersebut adalah adjung.

\section{(2) Frasa Preposisi Sebagai Komplemen}

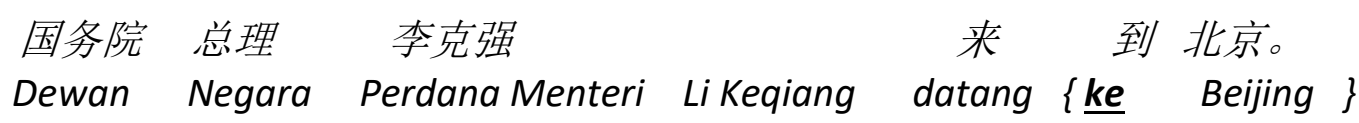

\section{BI: Perdana Menteri Dewan Negara Li Keqiang datang ke Beijing}

Pada kalimat di data no 12 di atas, terdapat preposisi 到 (dào - ke) sebagai Preposisi Lokatif, karena diikuti oleh nomina lokasi 北京 (Běijīng), sehingga membentuk FPrL yaitu 到 北京 (dào Běijīng-ke Beijing), FPrL 到 北京 (dào Běijīng) posisinya di belakang predikat verba 来 (lái - datang) melengkapi verba 来 (lái) maka fungsi sintaksisnya sebagai komplemen. Berikut ini adalah rekonstruksi kalimatnya :

a. *国务院 总理李克强来。 Dewan Negara Perdana Menteri Li Keqiang BI : Perdana Menteri Dewan Negara Li Keqiang datang.

b. * 国务院 总理李克强 $\{$ [ FPrepL[Prep 到 北京] $\}$ 来。 Dewan Negara Perdana Menteri Li Keqiang ke Beijing datang BI : Perdana Menteri Dewan Negara Li Keqiang ke Beijing datang

c. * $\{[$ F P rL [ Prep 到北京 ] \} 国务院总理李克强 $]\}$ 来。 Ke Beijing Dewan Negara Perdana Menteri datang BI : Ke Beijing Dewan Negara Perdana Menteri Li Keqiang datang.

Pada kalimat data (12a) FPrL 到 北京 (dào Běijīng - ke Beijing) dilesapkan, konstruksi ini dalam BM tidak berterima, baik secara makna maupun gramatikal. Sedangkan (12b) posisi FPrL 到 北京 (dào Běijīng - ke Beijing) dipindahkan ke depan predikat verba, hasilnya konstruksi ini juga tidak berterima secara makna maupun gramatikal. (12c) posisi FPr 到北京(dào Běijīng - ke Beijing) dipindahkan ke depan subyek, hasilnya juga tidak berterima secara makna maupun gramatikal. 
Dari hasil analisis di atas dapat disimpulkan bahwa FPrL 到北京(dào Běijīng - ke Beijing) berfungsi sebagai komplemen, sebab elemen itu diperlukan oleh preposisi 到 (dào - ke) yang menjadi intinya. Kalau komplemennya dihilangkan konstruksinya menjadi tidak gramatikal. Dalam X-bar struktur FP ini digambarkan sebagai berikut :

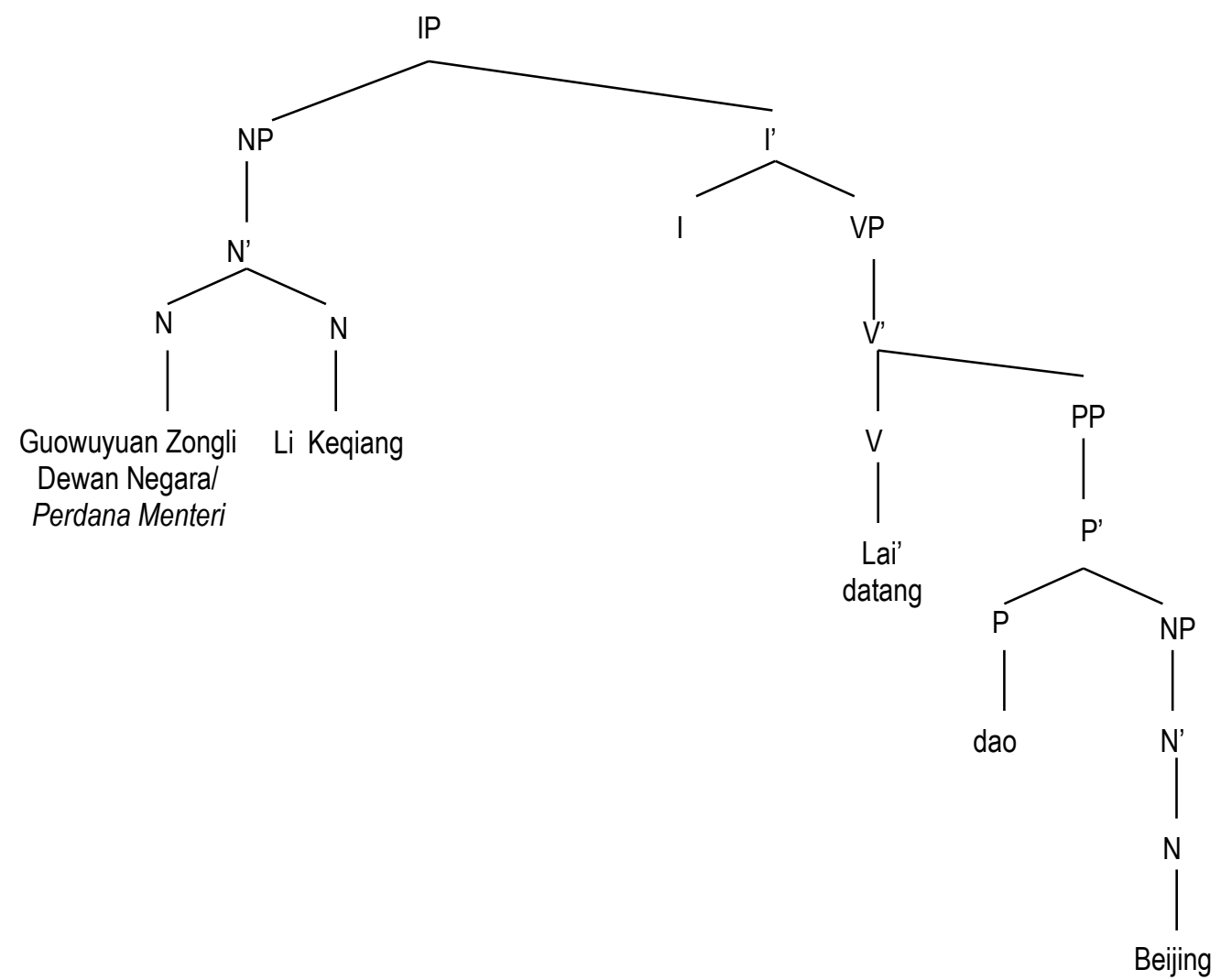

Dari diagram X-bar di atas terbukti posisi FPrL 到 北京 (dào Běijīng) fungsi sintaksisnya sebagai komplemen, karena letaknya di belakang sebelah kanan predikat verba 来 (lai-datang).

a. 印尼全国 \{[F P r T [ P r 自 2017 年 1 月 1 日 ] $\}$ 禁止出口原矿石 Indonesia nasional pada tahun Jan tanggal melarang ekspor biji mentah

BI : Indonesia dari tanggal 1 Januari melarang ekspor bijih mentah'

b. 印尼全国禁止出口\{[FPrT [ P r r 自 2017 年 1 月 1 日] $\}$ 原矿石。 Indonesia nasional melarang ekspor dari tahun bulan tanggal biji mentah $\mathrm{BI}$ : Indonesia melarang ekspor dari tanggal 1 Januari 2017 biji mentah.

c. 自 2017 年 1 月 1 日了\}印尼全国禁止出口原矿石。 Dari tahun bulan tanggal Indonesia nasional melarang ekspor mentah bijih BI : Dari tanggal 1 Januari 2017 Indonesia melarang ekspor bijih mentah. 
Pada rekonstruksi kalimat (25a) posisi preposisi 自 (zi - pada) adalah preposisi temporal, Frasa Preposisi Temporal 自 2017 年 1 月 1 日 (zì 2017 nián 1 yuè 1 rì - dari tanggal 1 Januari tahun 2017) terletak di depan predikat verba 禁止(jìnzhǐ - melarang), dalam BM kalimat ini berterima dan gramatikal, fungsi sintaksisnya sebagai adjung. Kalimat (25b) Frasa Preposisi Temporal 自 2017 年 1 月 1 日 (zì 2017 nián 1 yuè 1 rì - dari tanggal 1 Januari tahun 2017) di depan predikat verba 禁止 (jìnzhǐ - melarang). Frasa Preposisi Temporal 自 2017 年 1 月 1 日 (zì 2017 nián 1 yuè 1 rì) letaknya dipindah ke belakang predikat verba 禁止 (jìnzhǐ), maka kalimat ini secara gramatika tidak berterima, karena fungsi sintaksisnya sebagai adjung seharusnya letaknya di depan predikat verba, bukan di belakang predikat. Kalimat (25c), Frasa Preposisi Temporal 自 2017 年 1 月 1 日 (zì 2017 nián 1 yuè 1 rì ) apabila posisinya dipindah di depan subyek, maka kalimat (25c) tidak gramatikal dan tidak berterima karena dalam BM urutan FP yang berfungsi sebagai adjung posisinya selalu berada di depan predikat. Dari pembahasan diatas, dapat disimpulkan FP adalah adjung karena kehadiran konstituen ini pada kontruksi sintaksis bersifat opsional. Struktur frasanya direpresentasikan sebagai berikut:

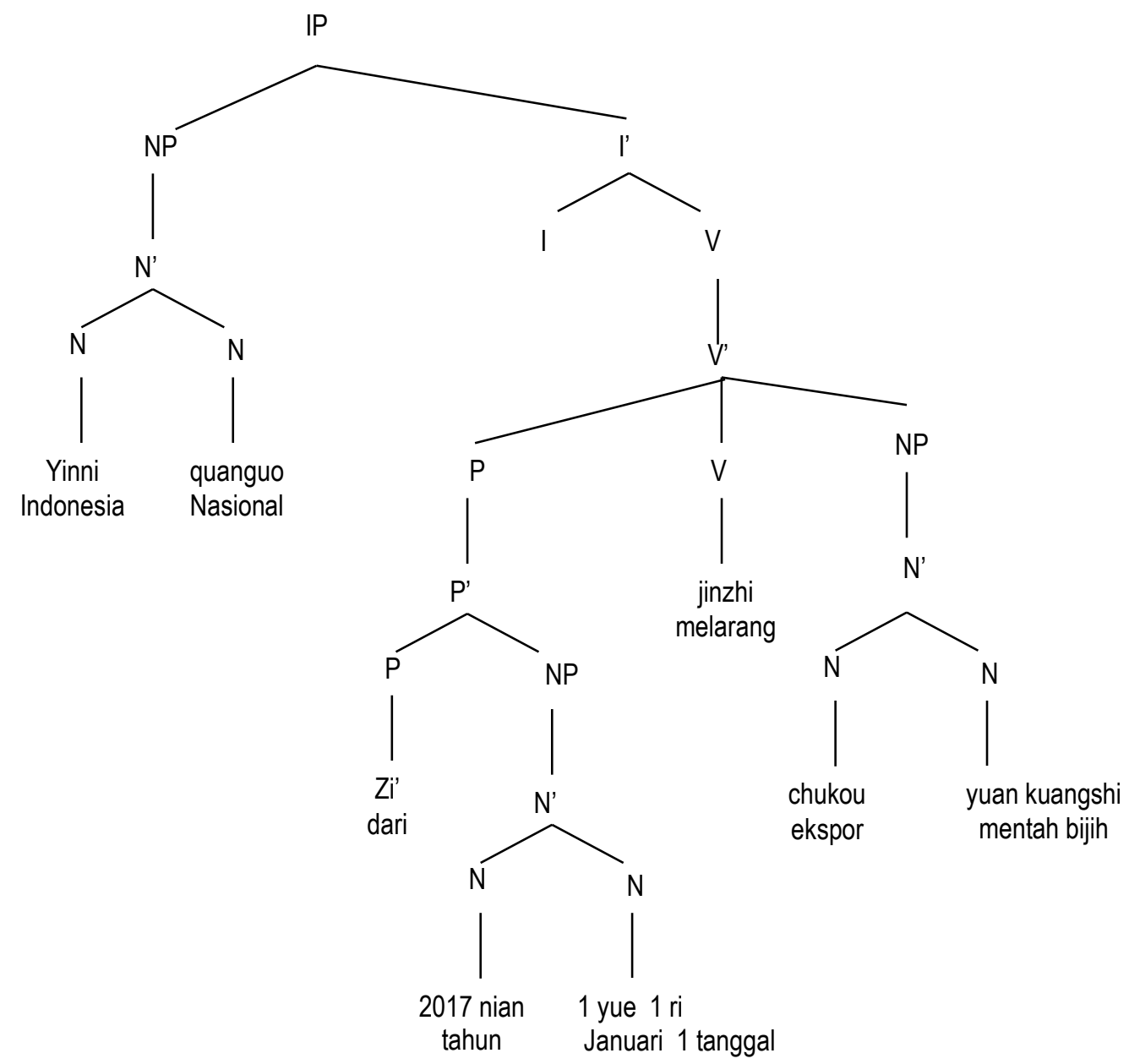


FP 自 2017 年 1 月 1 日 (zì 2017 nián 1 yuè 1 rì - dari tanggal 1 Januari 2017) adalah Frasa Preposisi Temporal karena dikuti oleh nomina kewaktuan. Berdasarkan diagram X-bar di atas terbukti bahwa fungsi sintaksisnya sebagai adjung, karena posisinya di depan predikat verba 禁止 (jìnzhǐ).

舞蹈 演员们 来 $\{[\mathrm{FPrL}[\mathrm{PrL}$ 自阿拉扎 大学 中文系的学生] $\}$

BI: Penari berasal dari mahasiswa jurusan Sastra Cina Universitas Al Azhar

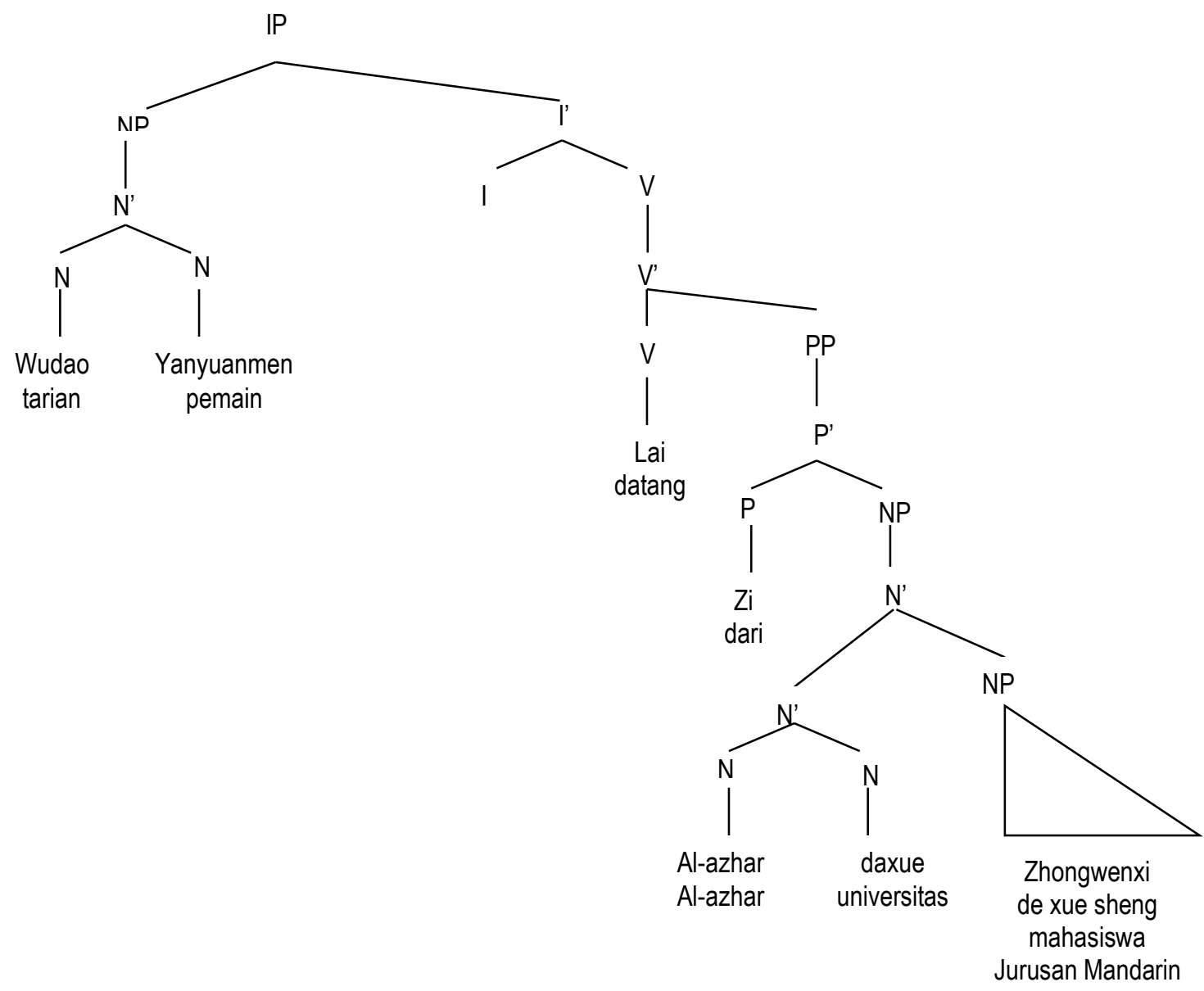

Dari diagram X-bar di atas terbukti bahwa Frasa Preposisi Lokatif 自阿拉扎 大 学中文系的学生（zì ālā zhā dàxué zhōngwén xi de xuéshēng-dari mahasiswa jurusan Sastra Cina Universitas Al Azhar) posisinya di belakang verba 来 (lái - datang). Maka fungsi sintaksisnya sebagai komplemen karena letaknya di sebelah kanan dari predikat verba 来 (lái). 
卡车 $\{[\operatorname{FPrL}[\operatorname{PrL}$ 在雅加达 7 个区] $\}$ 举办 连加 市场活动.

Truk di Jakarta wilayah menyelenggarakan operasi pasar

kegiatan

BI : Untuk menyelenggarakan kegiatan operasi pasar murah di 7 wilayah Jakarta di sediakan truk.

Pada kalimat (12) terdapat Frasa Preposisi Lokatif 在 7 雅加达 个区 (zài Yăjiādá 7 gè qū - di 7 wilayah Jakarta) yang fungsi sintaksisnya sebagai adjung, karena terletak di depan predikat verba 举办 (jǔbàn - mengadakan), berikut ini adalah diagram X-bar.

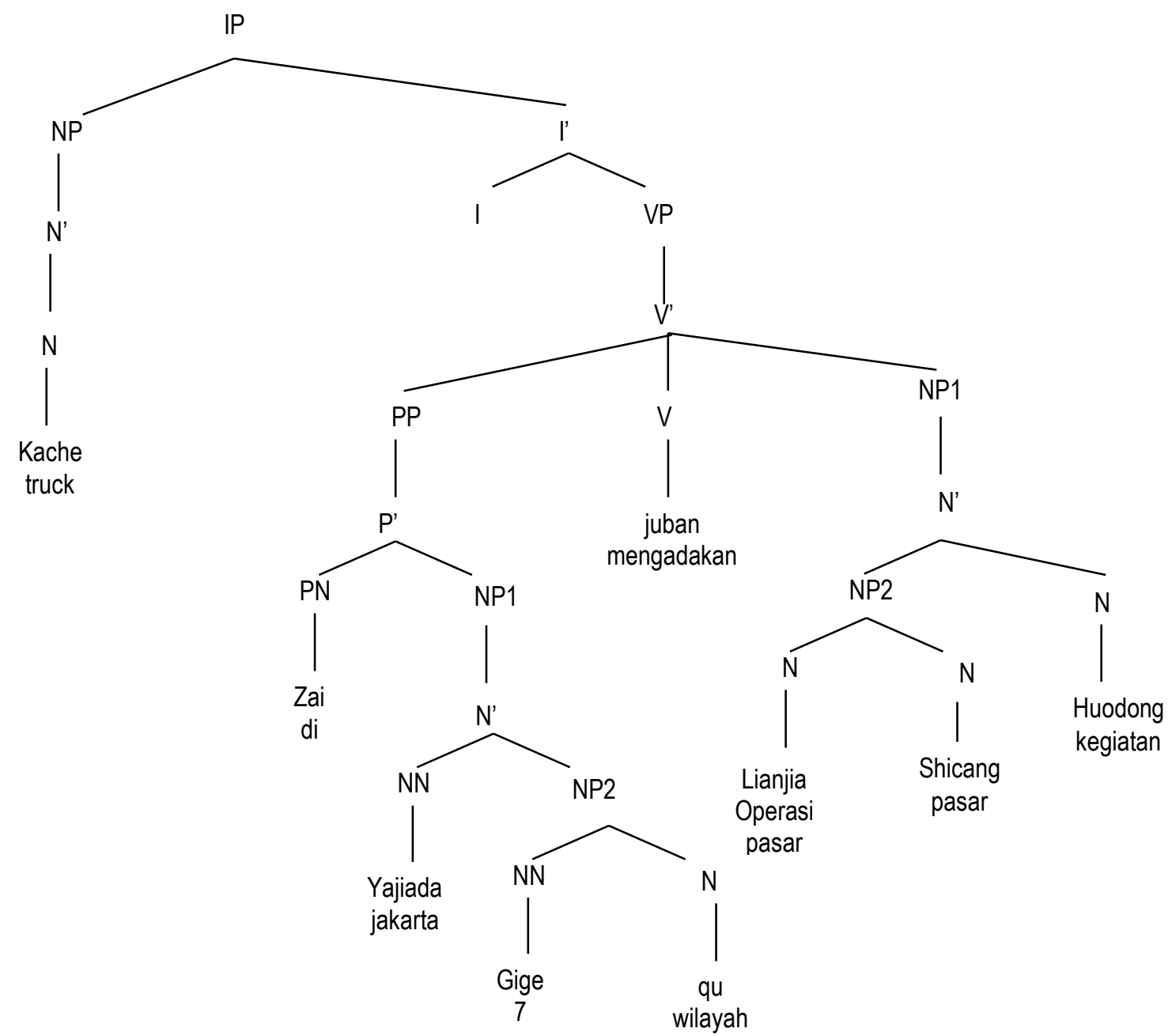

\section{Simpulan}

Dari hasil analisis pembahasan, penulis mengambil kesimpulan sebagai berikut : (1) preposisi 在 (zài-di), 于 (yú-di), 从 (cóng-dari), 自 (zì-dari) dan 到 (dào-ke) dapat berperan sebagai Preposisi Lokatif, Preposisi Temporal maupun gabungan keduanya 
(2) Preposisi在 (zài-di), 于 (yú-di), 从 (cóng-dari), 自 (zì-dari) dan 到 (dào-ke) jika bergabung menjadi FP dalam kalimat memiliki fungsi sintaksis sebagai adjung atau komplemen.

\section{DAFTAR PUSTAKA}

Anas. 2012. Yinní Xuéshēng Xí dé Hànyǔ Jiècí Duănyǔ "zài +NP" Shí Chángjiàn de Piān wù Fēnxī 《印尼学生习得汉语介词短语 “在 + NP” 时常见偏误分析》The Analysis of Common Error Made by Indonesian Students Learning Chinese Prepositional Phrase “在 + NP". Tesis. Fujian : Fujian Normal University.

Borong, Huang dkk. 1997. Xiàndài Hànyŭ 《现代汉语》 Bahasa Mandarin Modern. Beijing: Higher Education Press.

Dejin, Li dkk. 2011. A Practical Chinese Grammar for Foreigners. Beijing: Beijing Language \& Culture University Press.

Haegemen, L. 1992. Introduction to Government and Binding Theory. Oxford: Blackwell.

Li, Charles N. \& Thompson, Sandra A. 1981. A Functional Reference Grammar. California : University of California Press

Newson, Mark et.al. 2008. Basic English Syntax with Exercises. Budapest : Bolcsesz Konzorcium HEFOP Iroda.

Pujiono, Mhd. 2014. Analisis Frase Nominal Bahasa Jepang Berdasarkan Teori X-Bar (Suatu Kajian Sintaksis), from http://fib.unand.ac.id.

Radford, Andrew. 1997. Syntax : A Minimalist Introduction. 1997. Cambridge University Press. UK.

Sudaryanto. 1993. Metode dan Aneka Tehnik Analisis Bahasa: Pengantar Penelitian Wahana Kebudayaan secara Linguistik. Yogyakarta : Duta Wacana University Press.

Shuxiang, Lu. 2007. Xiàndài Hànyǔ Bā Băi Cí 《现代汉语八百词》 800 KataKata Mandarin Modern. Beijing: Commercial Press.

Shumei, Leng. 2008. Jiècí Duănyǔ "Zài $+X$ " de Jùfă Wèizhì Jí Jiècí "Zài" de Yìnxiàn Wèntí Kăochá 《介词短语“在 $+X$ ”的句法位置及介词“在”的隐现 问题考察》Research on the Syntactic Position of the Prepositional Phrase "Zai+ $X "$ and the Occurrence of the Preposition "Zai". Tesis. Beijing : Beijing Foreign Language \& Culture University. 
Tai, H.Y. James. 1985. Temporal Sequence and Chinese Word Order. http://ocw.nctu.edu.tw/course/famc021/RP09.pdf

Yuehua, Liu. 2005. Shǐyòng Hànyǔ Yǔfă 《使用汉语语法》 Tata Bahasa Mandarin Modern. Beijing: Commercial Press.

Zhen, Liang. 2008. Xiàndài Hànyǔ Zhòng Yǐnjìn Chùsuǒ, Shíjiān de Jiècí Zhī Bǐjiào Yánjiū 《现代汉语中引进处所、时间的介词之比较研究》 Perbandingan Preposisi Lokatif dan Temporal Bahasa Mandarin Modern. Tesis. Lanzhou : Lanzhou University.

Zelia, Vanya. 2012. Perbandingan Frasa Preposisi Bahasa Indonesia dan Bahasa Mandarin (Suatu Analisis Kontrastif). Tesis. Jakaarta : Universitas Negeri Jakarta.

\section{Data Penulis}

$\begin{array}{lll}\text { Nama } & : & \text { Titi Rahardjanti } \\ \text { Program Studi } & : & \text { Sastra China } \\ \text { Perguruan Tinggi } & : & \text { Universitas Bina Nusantara (Binus) } \\ \text { Hp } & : & 081291063009 \\ \text { Email } & : & \text { titi.leimeihui@gmail.com }\end{array}$




\section{DAFTAR SINGKATAN DAN LAMBANG SINGKATAN}

$\begin{array}{lll}\text { BM } & = & \text { Bahasa Mandarin } \\ \text { N } & = & \text { Noun } \\ \text { FP } & = & \text { Frasa Preposisi } \\ \text { V } & = & \text { Verba } \\ \text { S } & = & \text { Subyek } \\ \text { P } & = & \text { Predikat } \\ \text { O } & = & \text { Obyek } \\ \text { Adv. } & = & \text { Adverbia } \\ \text { VP } & = & \text { Verb Phrase } \\ \text { NP } & = & \text { Noun Phrase } \\ \text { FN } & = & \text { Frasa Nomina } \\ \text { GB } & = & \text { Government \& Binding Theory } \\ \text { TTG } & = & \text { Transformasi Gramatika Generatif } \\ \text { FV } & = & \text { Frasa Verbal } \\ \text { FA } & = & \text { Frasa Adjektival } \\ \text { FNum } & = & \text { Frasa Numeralia } \\ \text { P } & = & \text { Preposisi } \\ \text { Prep } & = & \text { Preposisi } \\ \text { FPrL } & = & \text { Frasa Preposisi Lokatif } \\ \text { FPrT } & = & \text { Frasa Preposisi Temporal } \\ \text { PrL } & = & \text { Preposisi Lokatif } \\ \text { PrT } & = & \text { Preposisi Temporal } \\ & & \end{array}$

\section{LAMBANG}

$=\quad$ Tidak Berterima

$=$ Mengapit Struktur Fungsional 